\title{
Does Church Participation Facilitate Tobacco Control? A Report on Korean Immigrants
}

\author{
C. Richard Hofstetter • John W. Ayers • Veronica L. Irvin • \\ D. Eastern Kang Sim • Suzanne C. Hughes • \\ Frederick Reighard $\cdot$ Melbourne F. Hovell
}

Published online: 10 February 2009

(C) The Author(s) 2009. This article is published with open access at Springerlink.com

\begin{abstract}
Background This study explores hypotheses linking church attendance to smoking prevalence, cessation, exposure to environmental tobacco smoke (ETS), and household smoking bans among Korean immigrants in California. Methods Data were drawn from telephone interviews with Korean adults $(N=2085)$ based on a probability sample during 2005-2006 in which $86 \%$ of those contacted completed interviews. Results Koreans who reported that they had attended church were less likely to be current smokers and to be exposed to ETS, and more likely to have quit smoking and to have a complete smoking ban than non-attenders after statistical controls for behavioral covariates. Discussion Whether or not participants reported attending church was associated with increased tobacco control practices. Public health interventions may profit by seeking to expand cooperation with religious congregations to facilitate efforts to promote
\end{abstract}

C. R. Hofstetter $(\bowtie)$

Department of Political Science and the Graduate School of Public Health, San Diego State University, 9245 Sky Park Court, Suite 230, San Diego, CA 92123, USA

e-mail: rhofstet@mail.sdsu.edu

URL: http://www-rohan.sdsu.edu/dept/polsciwb/people/faculty/ hoff.html

J. W. Ayers

Department of Health, Behavior and Society, Johns Hopkins

Bloomberg School of Public Health, Baltimore, MD, USA

V. L. Irvin - D. E. Kang Sim - S. C. Hughes .

F. Reighard · M. F. Hovell

Center for Behavioral Epidemiology and Community Health, Graduate School of Public Health, San Diego State University, San Diego, CA, USA

V. L. Irvin

Joint Doctoral Program in Public Health, University

of California, San Diego, CA, USA healthy lifestyles among immigrant populations beyond the influences of church attendance.

Keywords Korean · Church · Smoking · Cessation · Environmental tobacco smoke

\section{Introduction}

Religion and Health

Religious practice among some groups has been associated with health outcomes [1-5] including decreased mortality, risk of cancers and heart disease, and with increased immunity to disease, enhanced mental health, and self reports of general well-being [6-11]. About $80 \%$ of the studies in one review reported an association between religious practice and improved health status [12].

Several studies reported that longevity among diverse religious populations was a result of abstention from smoking and drinking [13-15]. Members of the Seventh Day Adventists Church had lower mortality rates than members of other religions in a 16 year longitudinal study, which was partially attributed to diet, non-smoking, and limited alcohol intake [16]. Mormon women had lower rates of cervical cancer than non-Mormon women as a result of non-smoking and healthier sexual practices [17].

Studies have assessed the role of voluntary associations, including churches, with help-seeking for psychiatric problems, occupational stress, contraceptive use, preventive screening, diet and exercise, disordered eating, and smoking cessation, but this research has not included Koreans and Korean immigrants to the U.S. [18-25]. For purposes of this study, the assumption is that participation in churches may expose people to systematic reinforcement of approved 
health behaviors. It also appears that small groups within Korean churches [26] constitute a particularly important set of interactions for Korean immigrants and would therefore be expected to have even greater influence over individual behaviors than among other groups. Many religious groups reinforce healthy habits, such as exercise, and discourage unhealthy practices, such as smoking, drinking, risky sexual practices, and use of illicit substances [27-31].

\section{Theoretical Framework}

From a behavioral perspective, churches are a type of voluntary association in which a series of patterned interactions governed by learned rules of behavior occurs. Small group formation is common around interactions within churches, and small group interaction influences behaviors of many kinds based on the extent to which rewarding relationships develop with others [32, 33]. Conforming behaviors are rewarded and deviant behaviors punished [34]; this includes health behaviors when health is a priority of the group $[35,36]$. Participation in voluntary associations, which involve face to face interaction, contribute to people building a sense of community [37, 38], although the consequences for health vary depending on the salience of health issues to each organization [39-41].

With regard to tobacco and religion, studies have identified a negative association between religious participation, identification, and smoking status and smoking initiation. The studies report a positive association between religious participation and smoking cessation within diverse research settings and among heterogeneous groups [42-44]. Whooley and associates reported that nonsmokers who attended religious services less than once a month were at a twofold greater risk of initiating smoking than were those who attended services regularly over a 3-year period [8]. In a focus group study, Kim et al. [45] suggested that church attendance was associated with smoking cessation as a result of social sanctions from fellow congregants.

\section{Korean Immigration and Religion}

Koreans immigrated to the U.S. largely following changes in American immigration laws since 1964. Most came from a culture in which it is traditional for men to smoke and women not to smoke. In behavioral analyses, social reinforcing contingencies for smoking (e.g., the presence of smoking models, gender, and acculturation) have consistently been related to smoking among Korean immigrants [46]. Male adults smoke at a much higher rate than female adults, although as men acculturate they smoke less and as women acculturate they smoke more [46, 47].

There were over 2,000 Korean churches in U.S. and the number of immigrant churches has grown faster than the
Korean population in the 1990s [48]. About $77 \%$ of Koreans in the U.S. are affiliated with Korean ethnic churches, and about $77 \%$ of these attend religious services at least once a week with $23 \%$ holding staff positions, e.g., minister, elder, or deacon. Approximately $74 \%$ of attendees reported that the main reason to attend church was religious, while $13 \%$ reported social reasons and $8 \%$ reported comfort/peace of mind (psychological) reasons. Social reasons were second for about $33 \%$ of attendees.

Church is a particularly important institution for Koreans in America, although the role of church may change with acculturation [48-51]. Korean churches function to: (1) be a social center and means of cultural identification for language and traditional values with others who share the same culture and values; (2) teach American-born Koreans language, history, and culture; (3) support Korean nationalism; (4) act as a pseudo-extended family; (5) broker between individuals and institutions of larger society; (6) provide emotional support for the distressed and those experiencing crises; and (7) serve as a reception center for immigrants [26, 52].

Korean immigrants tend to be Christian in religion and middle class in social status, some are ministers, and $75 \%$ are from Seoul. Immigration disrupts the familiar social networks, cultural norms, historical heritage, and sense of identity [52]. Christian background and current denominational affiliation provide continuity and meaning. Churches have been the most well-established social, cultural, and educational center for Koreans and are the most inclusive and accessible social institution for all Koreans in the United States. They provide frequent and regular opportunities for primary and secondary group interactions, social status, prestige, power, and recognition within immigrant community.

Korean middle class background is also a source of stress in the face of underemployment, labor market disadvantage, and social marginality, with a decrease in professional/technical employment after immigration [52]. Churches have provided a vehicle to preserve ethnic culture and identity especially since the U.S. emphasizes racial separatism and religious distinctiveness.

These findings and assumptions lead to the following hypotheses about church affiliation and smoking in the case of Korean immigrants:

(1) Church attendance is associated with reduced levels of smoking and exposure to environmental tobacco smoke (ETS) even after controlling for possible confounds; and

(2) Church attendance is associated with increased smoking cessation and bans on smoking within homes even after controlling for possible confounds. 


\section{Methods}

Participants

Telephone interviews were conducted with a probability sample of adults (18 years or over) of Korean descent who resided in households with residential telephones in California during 2005-2006 $(N=2085)$. The sample was drawn randomly from telephone numbers associated with persons with the 300 most common Korean surnames, a list that encompassed nearly all Koreans. A list was purchased from a commercial firm that had been derived from listed numbers and from other sources including membership lists, subscriptions, warrantee information, etc. Duplicates and persons whose first names were Asian but not distinctly Korean were purged from the list. This eliminated people with surnames that are common to Korea and to other nations (e.g., Ho, Cho) but who were not of Korean descent. Persons with Korean surnames and Anglicized first names were retained in the sample, and the list was then sorted into random order for interviewing. All potential respondents were filtered by interviewers to insure that they were of Korean descent during the introduction to the survey. Stratified by gender, respondents of Korean descent were then selected randomly in each household using the most recent birthday procedure [53].

Ineligible participants included non-Koreans, those at business telephone numbers, and persons who spoke neither Korean nor English. Disconnected numbers, answering machines, no answers, and continuous busy signals after up to 15 callbacks had been used were also excluded. A specially trained, skilled interviewer converted about $50 \%$ of initial refusals. Approximately $86 \%$ of all eligible respondents who were contacted completed interviews. Study procedures were approved by the Institutional Review Board at San Diego State University.

\section{Language}

Language is crucial in studies of recent immigrants since many health risks are associated strongly with acculturation $[46,54]$. The survey instrument was constructed in English and translated into Korean by bilingual staff. Precise wording was formulated based on feedback from two focus groups of Korean-Americans. The instrument was backtranslated, modified, and re-translated several times with the aid of study co-investigators who are senior faculty members at Myongji and Seoul National Universities in Korea and with local focus groups. All interviewers and their supervisor were bilingual in English and Korean. Since most Koreans are recent immigrants to the U.S., initial contact was made in Korean and interviewers were instructed to shift to English when respondents preferred.
About $86.4 \%$ of interviews were conducted in the Korean language.

The sampling procedure resulted in minor over-representation of older and under-representation of younger persons when compared to the most recent U.S. Census data available for the Korean population in California [55]. Intermarriage of Korean women and non-Korean men resulting in non-Korean surnames continues to be rare and no evidence of underrepresentation of this group was apparent in analyses [56]. Data were weighted to a recent age by gender adult census distribution although no significant differences appeared in conclusions from analyses using either weighted or unweighted data.

Measures: Dependent Variables

\section{CDC Smoking}

Smoking was measured by responses to: "Have you smoked 100 cigarettes during your lifetime?" $(32.5 \%)$ and "Do you now smoke cigarettes every day (11.2\%), some days $(2.1 \%)$, or not at all (86.6\%)?" [57] Current smokers $(13.3 \%)$ were those who had smoked 100 cigarettes and who said they now smoked cigarettes every day or some days.

\section{ETS Exposure}

Respondent exposure to environmental tobacco smoke (ETS) was measured by the sum of responses to "About how many cigarettes are you exposed to in your home during a typical day" $($ mean $=0.41, \mathrm{SD}=3.34)$, "...at work $\ldots$," (mean $=0.51, \mathrm{SD}=2.20)$ “...in a car...," (mean $=0.28$, $\mathrm{SD}=1.58)$ and “. $\ldots$ any other place...?" (mean $=0.42$, $\mathrm{SD}=0.49$ ) Dichotomizing the distribution at $0 v s$. more than 0 revealed $50.2 \%$ of the sample was exposed to ETS during a typical day.

\section{Cessation}

Respondents were classified as quitters (18.8\%) if they reported that they had ever used tobacco, had smoked at least 100 cigarettes, were successful in quitting (e.g., stayed quit until now), and had not smoked during the prior 90 days.

\section{Home Ban}

Home ban was coded 1 (86.8\%) if "no one was allowed to smoke in your home," and 0 otherwise. Previous publications have demonstrated that there is no substantial difference between no ban and a partial ban in exposure to ETS [58]. 
Measures: Church Attendance

\section{Church Attendance}

Respondents were classified as church attenders (75.8\%) by responses to "Do you attend church," coded Yes $=1$, otherwise 0 . Unfortunately, the dataset on which this paper was based did not include frequency of attendance.

Measures: Covariates

\section{Social Contingencies for Smoking}

A social contingencies scale for smoking was formed by computing the mean of reported smoking "encouragement" (coded 3), "discouragement" (coded 1), or other (coded 2) by spouse (mean $=1.49, \mathrm{SD}=0.51)$, parents $($ mean $=1.41$, $\mathrm{SD}=0.50)$, siblings $($ mean $=1.37, \mathrm{SD}=0.50)$, friends $($ mean $=1.48, \mathrm{SD}=0.55)$, children $($ mean $=1.53$, $\mathrm{SD}=0.50$ ), grandparents (mean $=1.70, \mathrm{SD}=0.46$ ), aunts and uncles (mean $=1.57, \mathrm{SD}=0.50)$, teachers $($ mean $=1.75, \mathrm{SD}=0.46)$, other persons $($ mean $=1.31$, $\mathrm{SD}=0.50$ ), and total scale (mean $=1.54, \mathrm{SD}=.32$, and Cronbach's $\alpha=.83$ ). This variable summarizes reinforcement to smoke/avoid smoking by significant others.

\section{Models of Smoking}

An index of models for smoking was computed by counting the number of the persons [spouse (9.9\%), parents (14.4\%), siblings (22.9\%), children (3.4\%), grandparents $(20.0 \%)$, aunts and uncles (27.3\%), and other persons (33.3\%)] who respondents reported “...regularly smok(ing) cigarettes." It was then transformed by computing the natural logarithm to constrain skewness $($ mean $=1.29, \mathrm{SD}=1.20)$.

\section{Acculturation to U.S. Society}

The acculturation scale used in this study was adapted from the Suinn-Lew Asian self-identity acculturation to U.S. society scale for telephone administration [59-61]. Items were designed to measure aspects of cultural preferences involving language, music, and self-identification including how the self is identified with the U.S. and Korea, and social linkages including ethnicity of peers and preferred associations. Reported proportions of education in the U.S. and proportion of years of age living in the U.S., items highly correlated with the other items, were added to the original scale.

After conversion to a common metric (z-scores), items were subjected to a principal components analysis. A single general dimension explained $65.9 \%$ of the total variance among items. Exact English and Korean wording of items, item loadings, means, and standard deviations are presented in Appendix Table 3. For purposes of analysis, a general acculturation to U.S. society scale was formed by computing the mean of standardized items (mean $=-.00$, $\mathrm{SD}=.81$, Cronbach's $\alpha=.93$ ) after permitting up to two scores to be missing. Analyses demonstrated that the missing data treatment made no significant difference in findings.

\section{Male by Acculturation Interaction}

An interaction term was computed based on coding gender male $=1$, female $=0$, and then multiplying this term by respondents' acculturation scores (mean $=0.06$, $\mathrm{SD}=0.56$ ). This variable was based on previous research with Koreans in which gender moderated acculturation associations with tobacco practices [62], and on theory [63] that men smoked less with acculturation and women smoked more with acculturation. The variable is included in analyses as a covariate to control for a possible confound.

\section{Demographic Variables}

Education was measured in years completed both in Korea and in the U.S (mean $=15.0, S D=3.31)$. Since some grades were commonly repeated after immigration, a composite measure was formed so that no common year was counted twice. Age was measured in years (mean $=44.2$, $\mathrm{SD}=17.39$ ), gender was determined by interviewers (42.2\% male), children were coded as present $(43.8 \%$ present) or absent. Marital status was coded 1 for married or cohabiting (67.3\%), and 0 otherwise.

\section{Participants}

Mean age of respondents was 44.2 years $(\mathrm{SD}=17.4)$ years, $90.4 \%$ were born in Korea, and $98.8 \%$ of parents were born in Korea (Table 1). Respondents reported living longer in Korea $($ mean $=26.2$ years, $S D=16.4)$ than in the U.S. (mean $=17.0$ years, $S D=10.5)$. Mean years of education were also higher in Korea $(11.2$ years, $\mathrm{SD}=6.1)$ than in the U.S. ( 4.2 years, $S D=6.0$ ). About $42.2 \%$ of respondents were male, $48.4 \%$ worked outside the home, $23.8 \%$ were single, $67.3 \%$ married, $6.8 \%$ widowed, and $2.1 \%$ divorced or separated. About $75.8 \%$ reported attending church.

\section{Analysis Plan}

Multiple logistic regression analyses and descriptive statistics for this study were computed using SPSS (version 16.0) and STATA (version 10.0). Tests of hypotheses using the multivariate analyses were used to control the 
Table 1 Demographic characteristics of the sample ${ }^{a}$

\begin{tabular}{|c|c|c|c|}
\hline Demographic & Mean & SD & $N$ \\
\hline Age of respondent & 44.2 & 17.4 & 2085 \\
\hline Years resident in Korea & 26.2 & 16.4 & 2079 \\
\hline Years resident in U.S. & 17.0 & 10.5 & 2079 \\
\hline Years education in Korea & 11.2 & 6.1 & 2085 \\
\hline Years education in U.S. & 4.2 & 6.0 & 2085 \\
\hline \multirow[t]{2}{*}{ Household annual income } & $\$ 53,164$ & $\$ 41,660$ & 719 \\
\hline & \multicolumn{2}{|c|}{ Percent } & \\
\hline Male & \multicolumn{2}{|c|}{42.2} & 2085 \\
\hline Working outside the home & \multicolumn{2}{|c|}{48.4} & 2075 \\
\hline Born in Korea & \multicolumn{2}{|c|}{90.4} & 2083 \\
\hline Parents born in Korea & \multicolumn{2}{|c|}{98.8} & 2085 \\
\hline Interviewed in Korean language & \multicolumn{2}{|c|}{86.4} & 2081 \\
\hline \multicolumn{4}{|l|}{ Marital status } \\
\hline Single & \multicolumn{2}{|c|}{23.8} & 2071 \\
\hline Married & \multicolumn{2}{|c|}{67.3} & \\
\hline Widowed & \multicolumn{2}{|c|}{6.8} & \\
\hline Divorced & \multicolumn{2}{|c|}{2.1} & \\
\hline Other & \multicolumn{2}{|c|}{0.3} & \\
\hline
\end{tabular}

a $49.9 \%$ stated that they "did not know" their household income, and $15.6 \%$ refused to answer. Income is not used in the analysis due to missing data

associations between church attendance and tobacco behaviors for possible confounds.

\section{Results}

\section{Smoking Behaviors}

About $13.0 \%$ reported that they were current smokers by CDC criteria, and $50.2 \%$ that they had some daily exposure to environmental smoke at home, work, in a car, or somewhere else. About $57.1 \%$ of those classified as former smokers reported having quit for 90 days or more, and $86.8 \%$ reported that they had a ban against smoking anywhere in their home.

\section{Analysis}

Bivariate logistic regression analysis supports the hypotheses that church attenders are less likely to smoke $(\mathrm{OR}=.334, P<.001)$ and to be exposed to ETS $(\mathrm{OR}=$ $.318, P<.001)$, and more likely to quit $(\mathrm{OR}=2.114$, $P<.001)$ and to ban smoking in their homes $(\mathrm{OR}=$ 2.311, $P<.001)$.

But these associations could prove to be spurious unless the associations are subject to controls for other predictors of tobacco behavior and church attendance. Earlier research demonstrated that social reinforcers (social support and models), acculturation, gender, gender by acculturation interactions, age, and education are associated with a variety of tobacco behaviors among Korean immigrants [46, 54, 64-66].

Results reported in Table 2 show that these covariates continue to be related to each tobacco behaviors in many cases.

Data in Table 2 show that church attendance is related to decreased smoking status $(\mathrm{OR}=.491, P<.001$, Nagelkerke $\left.R^{2}=.31\right)$ and decreased exposure to ETS $(\mathrm{OR}=.463$, $P<.001$, Nagelkerke $\left.R^{2}=.20\right)$, and to increased smoking cessation $\left(\mathrm{OR}=1.517, P<.026\right.$, Nagelkerke $\left.R^{2}=.24\right)$ and increased smoking bans in the home $(\mathrm{OR}=1.807, P<.001$, Nagelkerke $R^{2}=.10$ ) after controlling for covariates. The unique contribution of church attendance (after controlling for other predictors) to Nagelkerke $R^{2}$ is about $2 \%$ for smoking status, ETS exposure, and smoking bans in the home, and $1 \%$ for cessation. The covariates include powerful predictors of tobacco behaviors, social support and the presence of persons who model smoking behavior. The covariates also include indicators of acculturation and gender as well as the interaction between the two. These variables have been tied to tobacco behaviors among Koreans. Finally, covariates include social variables which are related to both church attendance and tobacco behaviors including marital status, children in the home, education, and age.

Thus, tests of associations between church attendance and the dependent variables are particularly stringent, and provide evidence to support the conclusion that the associations involving these associations are not due to self selection or to other potentially confounding factors. The significance of the findings can be illustrated by estimating the difference in probabilities for smoking, cessation, exposure to ETS, and home bans between church attenders and non-attenders when other predictors are set to their means.

The differences in probability of each form of tobacco behavior when other predictors are set to their means can be interpreted as the influence of church attendance for the otherwise "average" respondent [67]. Church attenders were $5.37 \%(95 \% \mathrm{CI}-.082,-.025)$ less likely to be current smokers in comparison to the otherwise average non-attendee. This decrease may seem small but considering that the probability of being a smoker is only .113 when all variables set to their means, church attendees were half as likely to smoke as their non-church attender counterparts. Church attenders were $6.57 \%(95 \% \mathrm{CI}-.096,-.034)$ less likely to be exposed to environmental tobacco smoke in comparison to the otherwise average non-attender. Church attenders who ever smoked were $11.63 \%$ (95\% CI .026, .205) more likely to have quit smoking and stayed quite for 90 days and $7.24 \%$ 
Table 2 Logistic regression of smoking status, ETS exposure, smoking cessation, and no smoking bans in home regressed on church attendance, and selected social learning and demographic predictors ${ }^{\mathrm{a}}$

\begin{tabular}{|c|c|c|c|c|c|c|c|c|}
\hline \multirow[b]{2}{*}{ Predictor } & \multicolumn{4}{|c|}{ CDC smoking status } & \multicolumn{4}{|c|}{ Respondent ETS exposure } \\
\hline & B & SE & OR & $P$ & $\mathrm{~B}$ & SE & OR & $P$ \\
\hline Church attendance & -.710 & .159 & .491 & .000 & -.768 & .169 & .463 & .000 \\
\hline Smoking support & 1.054 & .194 & 2.871 & .000 & .824 & .201 & 2.280 & .000 \\
\hline Presence of models & 1.149 & .167 & 3.157 & .000 & 1.227 & .183 & 3.414 & .000 \\
\hline Male acculturation & -.556 & .195 & .573 & .004 & -.260 & .213 & .770 & .222 \\
\hline Female acculturation & .138 & .171 & 1.148 & .419 & -.246 & .180 & .781 & .173 \\
\hline Male gender & 2.034 & .180 & 7.649 & .000 & .956 & .168 & 2.601 & .000 \\
\hline Married/cohabiting & -.199 & .233 & .819 & .394 & -.490 & .228 & .612 & .031 \\
\hline Children in home & -.146 & .182 & .863 & .422 & -.207 & .192 & .812 & .280 \\
\hline Education & -.063 & .027 & .938 & .019 & -.057 & .027 & .944 & .036 \\
\hline Age & -.017 & .007 & .982 & .014 & -.003 & .007 & .996 & .634 \\
\hline \multirow[t]{5}{*}{ Constant } & -3.231 & .626 & & .000 & -3.002 & .652 & & .000 \\
\hline & \multirow{3}{*}{\multicolumn{4}{|c|}{$\begin{array}{l}\chi_{(10)}^{2}=356.20, P=.001 \\
\text { Nagelkerke } R^{2}=.31, N=1925 \\
\text { Added by church } R^{2}=.02\end{array}$}} & \multirow{3}{*}{\multicolumn{4}{|c|}{$\begin{array}{l}\chi_{(10)}^{2}=192.00, P=.001 \\
\text { Nagelkerke } R^{2}=.20, N=1925 \\
\text { Added by church } R^{2}=.02\end{array}$}} \\
\hline & & & & & & & & \\
\hline & & & & & & & & \\
\hline & \multicolumn{4}{|c|}{ Cessation } & \multicolumn{4}{|c|}{ Smoking bans in home } \\
\hline Church attendance & .417 & .187 & 1.517 & .026 & .592 & .150 & 1.807 & .000 \\
\hline Smoking support & -.758 & .237 & .468 & .001 & .010 & .181 & 1.010 & .955 \\
\hline Presence of models & -.732 & .188 & .480 & .000 & -.650 & .149 & .521 & .000 \\
\hline Male acculturation & -.154 & .253 & .856 & .541 & .001 & .179 & 1.001 & .992 \\
\hline Female acculturation & .295 & .224 & 1.343 & .187 & .374 & .144 & 1.454 & .009 \\
\hline Male gender & -.132 & .223 & .875 & .552 & -.149 & .144 & .861 & .300 \\
\hline Married/cohabiting & .341 & .255 & 1.407 & .180 & .218 & .187 & 1.243 & .245 \\
\hline Children in home & .060 & .207 & 1.062 & .771 & .876 & .171 & 2.402 & .000 \\
\hline Education & .082 & .030 & 1.086 & .006 & .047 & .023 & 1.048 & .041 \\
\hline Age & .035 & .008 & 1.036 & .000 & .012 & .005 & 1.012 & .032 \\
\hline \multirow[t]{4}{*}{ Constant } & -1.245 & .752 & & .098 & .310 & .551 & & .573 \\
\hline & \multicolumn{4}{|c|}{$\chi_{(10)}^{2}=124.57, P<.001$} & \multicolumn{4}{|c|}{$\chi_{(10)}^{2}=109.94, P<.001$} \\
\hline & \multicolumn{4}{|c|}{ Nagelkerke $R^{2}=.24, N=642$} & \multicolumn{4}{|c|}{ Nagelkerke $R^{2}=.10, N=1925$} \\
\hline & \multicolumn{4}{|c|}{ Added by church $R^{2}=.01$} & \multicolumn{4}{|c|}{ Added by church $R^{2}=.02$} \\
\hline
\end{tabular}

\footnotetext{
${ }^{a}$ Numbers in cells are regression coefficients, standard errors, odds ratios, and associated probabilities for regression of column heading on selected predictors. Goodness of fit statistics and associated probabilities are below each subtable. Nagelkerke $R^{2}$ is an indicator or the proportion of deviance reduced by all predictors and the contribution of church attendance after controlling for other predictors is indicated by church $R^{2}$. CDC smoking status was coded 1 when respondents reported smoking 100 or more cigarettes in their life and currently smoked every day or some days or 0 otherwise. ETS exposure was coded 1 when respondents reported being exposed to one or more cigarettes during an average week or 0 otherwise. Cessation was based on former smokers only and coded 1 when respondents reported having quit smoking or 0 otherwise. Reported smoking bans in the home were coded 0 , or 1 when no bans were reported. Male was coded 1 if respondent were male or 0 otherwise. Male acculturation was computed by multiplying male by acculturation. The total sample $N=2085$, although cases with missing data were deleted in computations
}

$(95 \%$ CI $.034, .110)$ more likely to have a full home ban on smoking in comparison to non-attenders.

\section{Discussion}

Analysis of data from a large, representative probability sample of adults of Korean descent residing in California revealed that church attendance was associated with decreased risk in tobacco related behaviors in the form of smoking and exposure to environmental tobacco smoke. Church attendance was also associated with increased reports of smoking cessation and complete bans of smoking in the home. Although prior predictors of tobacco behaviors were also related to the tobacco behaviors in accord with expectations, the associations between church 
attendance and tobacco related behaviors remained robust even after these predictors were controlled statistically. These findings suggest that church attendance may be an important predictor of tobacco behavior among people of Korean descent in America.

Unlike other studies, we presented evidence that relates to a series of smoking behaviors suggesting that church attendance influences more than just someone's behavior to smoke or not. The influence of church is a matter of serious importance among Koreans, a vulnerable and rapidly growing minority, who become actively religious as a possible consequence of the institution facilitating the immigration experience. Nearly all participants in this study were recent immigrants (over 90\% were born in Korea), and nearly all of those who attended religious ceremonies in the U.S. attended Christian churches. Church attendance is high among Koreans in America [48, 49], at least partially due to the critical roles that churches play for recent immigrants in adapting to life in America [63].

The formation of small cellular groups in Korean churches is important for acculturation and adaptation to American life [38] and the dynamics of interaction within such groups may be particularly efficacious in diminishing tobacco and other health risk behaviors that had been culturally appropriate in Korea. These contingencies take place in formal congregation and other informal church related meeting. Thus, while the church may provide a context for interacting with others, the social norms that are acquired and influence congregants in a given church may also generalize to influencing behavior in the broader community. We expect that the influences on behavior involved are compounded by the significance that churches have for Koreans and by the anti-tobacco social sanctions within the broader California culture and legal system.

This study suggests that Koreans are influenced by church attendance in ways similar to others. Church attendance is generally healthy in that it is associated with various diminished health risk behaviors [1, 2, 13] including diminished smoking [8]. Unfortunately, much of this research does not focus on the mechanisms of influence [2] which is also a weakness of this study. Within the limits of a secondary analysis, the present study shows relationships that we have assumed to act as markers for social processes that account for the associations between church memberships and health risks, and almost all such hypotheses were verified by our results. However, future studies should provide more comprehensive analyses of theoretical mechanisms by which church attendance influences healthy lifestyle practices.

Several explanations of these findings are possible. It is unlikely, for instance, that non-smokers self selected to attend church more than others. If self selection were involved it was not based on gender, age, education, children in the home, or acculturation since these variables were controlled in the multivariate analyses. A more likely explanation that was not directly measured in these data is that participants who attended churches were engaged in social behaviors that reinforced healthier tobacco habits. Church doctrines often emphasize that the human body should not be harmed willfully. In the course of interaction with other congregants and with church officials it becomes clear that smoking is undesirable, harmful, and social criticisms may be brought to bear that punish tobacco use. Health practices may be further reinforced by clergy and other church officials. Preliminary findings from recent focus groups with adults of Korean descent support these explanations [68].

As with some other voluntary associations, churches may facilitate health by establishing social networks that compensate for limited access to health care and public health services [69]. Group participants exchange information and evaluate peers' approval or disapproval of the new behaviors [70]. Interventions may mobilize the social relationships within voluntary associations to promote preventive health behaviors beyond those normally occurring in such groups [71]. Such interventions rely primarily on interpersonal communication, adapted to the cultures of the groups involved. In the case of immigrant groups new to America, such as most Koreans, interventions should be tailored to language, age, and gender of those involved, and include a range of cooperative activities within the context of congregations. Interventions should also be led by members of the congregation who are trained to conduct discussions, activities, and to prepare materials for groups in Korean as well as English.

Church attendance as measured in this study was not an intervention. However, the association between Korean church participation and diminished exposure to tobacco suggests that cooperative efforts may enhance these associations [72]. Cooperation between churches and public health personnel have produced positive outcomes in reducing health risk practices. Involving churches in practices that they already support, such as tobacco control, may be an effective way to reach relatively insular communities such as Koreans who are recent immigrants many of whom speak limited English and who have high levels of church attendance [73]. Cooperative efforts with religious institutions may provide a link between public health efforts and minority communities that are otherwise difficult to reach such as recent Korean immigrants [74]. The cooperation on the part of public health interveners might involve preparing materials (in Korean and English), recruiting, training, and supporting Korean participants who are church members to lead discussions, presenting information in a variety of formats, and designing special programs promoting health and reducing health risks. 
Tobacco is a particular risk among Korean males, but, as we have noted, Korean women also increase tobacco risk as they become acculturated in California [46]. Research also indicates that Korean youth are highly susceptible to tobacco use [65].

Of course, one must be cautious about inferring causality from cross sectional data, but the current findings are based on one of the few large probability samples of adult Koreans in a state that includes one-third of all Koreans in the U.S. It is also based on theoretical models that have been vetted by animal and experimental studies with people and from which tentative support for probable causal effects is justified [75-77].

We assume that the patterns of reinforcement regarding tobacco risk constitute the major mechanism that accounts for the association between church attendance and tobacco risk behaviors in this study. Christian churches are particularly salient institutions to Koreans in part for historical reasons and in part because they function to aid recent immigrants adjusting to American society. For these reasons, we assume that the model will apply to a greater extent to new immigrant groups that have strong religious traditions, such as Mexicans, compared to recent immigrant groups that do not originate from cultures that have strong religious traditions. However, this model may also apply to other institutions that facilitate adaptation to America such as family associations among contemporary Chinese immigrants from the Peoples' Republic of China.

Unfortunately, frequency of church attendance was not measured in the survey and it was therefore impossible to assess a "dose effect" of attendance, and the generalization of findings may therefore be limited. Greater exposure to social reinforcers is assumed to be related to greater influence. Not only should frequency of church attendance be measured, but also the personal salience of church attendance and the content of social interaction within the church setting regarding health topics. Such measures will strengthen the evidence for mechanisms by which church attendance may promote healthy lifestyles. More conclusive evidence of the mechanisms involved in church participation and its influence on health behaviors awaits subsequent analyses.

\section{Conclusions}

This study showed that previously reported associations between church attendance and lifestyle practices may be due to social contingencies within congregations. Results showed significant associations between social contingencies and smoking status, quitting, ETS exposure, and home bans on smoking, all in the theoretically expected direction, for a large and growing group of Korean immigrants. It also contributes to a growing literature on the impact of institutions on tobacco behaviors and raises questions concerning immigrant dependency on religious institutions in America as they accommodate the demands of their new home. Finally, this study adds to the empirical understanding of how ecological factors may influence lifestyle practices.

Acknowledgements The project described was supported by a Grant to C. Richard Hofstetter, R01CA105199, from the National Cancer Institute. The content is solely the responsibility of the authors and does not necessarily represent the official views of the National Cancer Institute or the National Institutes of Health. Intramural support was received from the Center for Behavioral Epidemiology and Community Health. We wish to thank the referees for this journal and Tara Beeston, Center for Behavioral Epidemiology and Community Health, Graduate School of Public Health, San Diego State University, San Diego, California, USA, for many helpful suggestions.

Open Access This article is distributed under the terms of the Creative Commons Attribution Noncommercial License which permits any noncommercial use, distribution, and reproduction in any medium, provided the original author(s) and source are credited.

\section{Appendix}

Table 3 Principal component of acculturation among people of Korean descent in California ${ }^{\mathrm{a}}$

\begin{tabular}{|c|c|c|c|}
\hline Item & Loading & Mean & SD \\
\hline $\begin{array}{l}\text { 1. Do you speak Korean only, mostly Korean } \\
\text { with some English, Korean and English } \\
\text { equally well, mostly English, or English } \\
\text { only? }\end{array}$ & .917 & 2.6 & .9 \\
\hline 2. Which language do you prefer to speak? & .902 & 1.4 & .7 \\
\hline $\begin{array}{l}\text { 3. What was the ethnic origin of the friends } \\
\text { and peers you had, as a child up to age } 6 \text { ? } \\
\text { Was it almost exclusively Korean, mostly } \\
\text { Korean, equally Korean and non-Korean, } \\
\text { mostly non-Korean, or almost exclusively } \\
\text { non-Korean? }\end{array}$ & .870 & 1.3 & 9 \\
\hline $\begin{array}{l}\text { 4. What was the ethnic origin of the friends } \\
\text { and peers you had, as a child from } 6 \text { to } 18 \text { ? } \\
\text { Was it almost exclusively Korean, mostly } \\
\text { Korean, equally Korean and non-Korean, } \\
\text { mostly non-Korean, or almost exclusively } \\
\text { non-Korean? }\end{array}$ & .854 & 1.6 & 1.0 \\
\hline $\begin{array}{l}\text { 5. With regard to music do you prefer only } \\
\text { Korean music, mostly Korean music, } \\
\text { equally Korean and non-Korean music, } \\
\text { mostly non-Korean music, or non-Korean } \\
\text { music only? }\end{array}$ & .847 & 2.9 & 1.1 \\
\hline $\begin{array}{l}\text { 6. When reading, do you read only Korean, } \\
\text { read Korean better than English, read both } \\
\text { Korean and English equally well, read } \\
\text { English better than Korean, or read only } \\
\text { English? }\end{array}$ & .794 & 2.4 & 1.3 \\
\hline
\end{tabular}


Table 3 continued

\begin{tabular}{lccr}
\hline Item & Loading & Mean & SD \\
\hline $\begin{array}{l}\text { 7. What is your food preference in restaurants? } \\
\text { Do you prefer Korean food exclusively, }\end{array}$ & .779 & 1.1 & .3 \\
$\begin{array}{l}\text { mostly Korean food, about equally Korean } \\
\text { and American food, mostly American food, }\end{array}$ & & & \\
$\begin{array}{l}\text { or exclusively American food? } \\
\text { 8. Percentage years of life in the U.S. }\end{array}$ & .658 & 42.1 & 27.4 \\
9. Percentage years of education in U.S. & .628 & 25.8 & 36.5 \\
$\quad$ (highest meaningful combined years) & & & \\
Percent total variance & $65.9 \%$ & & \\
\hline
\end{tabular}

${ }^{a}$ Numbers in cells are component loadings, item means, item standard deviations, and the percentage of total variance the principal component explains. Korean translation of items were

1. 한국말만 쓰십니까, 대부분 한국말을 쓰되 약간의 영어, 한국 말과 영어 반반씩, 대부분 영어, 아니면 영어만 쓰십니까?

2. 한국말과 영어 중 어떤 말이 더 편하십니까?

3. 본인이 여섯살 때까지 같이 어울렸던 친구들은 “전부 한국인”, “대부분 한국인”, "반반 정도”, "대부분 외국인”, “전부 외국인” 중 어디에 해당됩니까?

4. 본인이 여섯살 이후 18 세까지 같이 어울렸던 친구들은 “전부 한국인”, “대부분 한국인”, “반반 정도”, “대부분 외국인”, “전부 외국인" 중 어디에 해당됩니까?

5. 어떤 종류의 음악을 선호하십니까? “한국음악만”, “대부분 한 국음악”, “한국 음악과 외국 음악을 비슷하게”, “대부분 외국음 악", "외국음악만" 중에서 어느 것입니까?

6. 어떤 종류의 음악을 선호하십니까? “한국음악만”, “대부분 한 국음악", “한국 음악과 외국 음악을 비슷하게”, “대부분 외국음 악", "외국음악만” 중에서 어느 것입니까?

7. 책을 읽으실 때, 한국어로 된 책만 읽는다, 영어로 된 책보다 한 국어로 된 책을 더 잘 읽는다, 둘 다 잘 읽는다, 한국어로 된 책보 다 영어로 된 책을 더 잘 읽는다, 아니면 영어로 된 책만 읽는다 중 에서 어느 것에 해당되십니까?

8. 사람들은 자신을 다양한 모습으로 생각 할 수 있습니다. 다음 항목 중 어느 항목이 본인을 가장 잘 나타낸다고 생각하는지 말씀 해 주십시오. 나는 근본적으로 국인이라고 생각한다. 비록 미국 에서 일하며 살고 있더라도 나 자신을 한국사람이라고 본다. 나는 근본적으로 미국인이라고 생각한다. 비록 한국인의 배경과 특성 을 가지고 있더라도, 나 자신을 미국사람이라고 본다.

9. 한국에서 몇년간 사셨습니까? 미국에서 몇년간 사셨습니까? 10. 한국에서 몇년간 정규학교에 다니셨습니까? 최종 몇 학년까 지 마치셨습니까? 미국에서 몇년간 정규학교에 다니셨습니까? 최종 몇 학년까지 마치셨습니까?

\section{References}

1. Chatters LM. Religion and health: public health research and practice. Annu Rev Public Health. 2000;21:335-67.

2. George LK, Ellison CG, Larson DB. Explaining the relationships between religious involvement \& health. Psychol Inq. 2002;13: 190-200.

3. George LK, Larsons DB, Koeing HG, McCullough ME. Spirituality and health: what we know, what we need to know. J Soc Clin Psychol. 2000;19:102-16.

4. Koenig HG, McCullough ME, Larsen DB. Handbook of religion \& health. New York: Oxford University Press; 2001.

5. Smith C. Theorizing religious effects among American adolescents. J Sci Study Relig. 2003;42(1):17-30.
6. Kark JD, Shemi G, Friedlander Y, Martin O, Manor O, Blondheim SH. Does religious observance promote health? Mortality in secular vs. religious kibbutzim in Israel. Am J Public Health. 1996;86(3):341-6.

7. Merrill RM, Hilton SC, Daniels M. Impact of the LDS church's health doctrine on deaths from diseases and conditions associated with cigarette smoking. Ann Epidemiol. 2003;13(10):704-11.

8. Whooley MA, Boyd AL, Gardin JM, Williams DR. Religious involvement and cigarette smoking in young adults: The CARDIA study (Coronary Artery Risk Development in Young Adults). Arch Intern Med. 2002;162:1604-10.

9. Koenig HG, Cohen HJ, George LK, Hays JC, Larson DB, Blazer DG. Attendance at religious services, interleukin-6, and other biological parameters of immune function in older adults. Int $\mathbf{J}$ Psychiatr Med. 1997;27:233-50.

10. Larson DB, Sherrill KA, Lyons JS, Craigie FC Jr, Theilman SB. Associations between dimensions of religious commitment and mental health. Reported in the American Journal of Psychiatry and Archives of General Psychiatry: 1978-1989. Am J Psychiatry. 1992;149:557-9.

11. Barkan SE, Greenwood SF. Religious attendance and subjective well-being among older Americans: evidence from the General Social Survey. Rev Relig Res. 2003;45(2):116-29.

12. Matthews DA, McCullough ME, Larson DB, Koenig HG, Swyers JP, Milano MG. Religious commitment and health status. Arch Fam Med. 1998;7:118-24.

13. Strawbridge WJ, Cohen RD, Shema SJ, Kaplan GA. Frequent attendance at religious services and mortality over 28 years. Am J Public Health. 1997;87:957-61.

14. Levin JS. Religion and health: is there an association, is it valid, and is it causal. Soc Sci Med. 1994;38:1475-82.

15. Ellison CG. Religion, the life stress paradigm, and the study of depression. In: Levin JS, editor. Religion in aging and health: theoretical foundations and methodological frontiers. Thousand Oaks: Sage; 1994. p. 28-121.

16. Phillips RL, Kuzma JW, Benson WL, Lotz T. Influence of selection versus lifestyle on risk of fatal cancer and cardiovascular disease among seventh-day adventists. Am J Epidemiol. 1980;112:296-314.

17. Gardner JW, Sanborn JS, Slattery ML. Behavioral factors explaining the low risk for cervical carcinoma in Utah Mormon women. Epidemiology. 1995;6(2):187-9.

18. Fosu GB. Women's orientation toward help-seeking for mental disorders. Soc Sci Med. 1995;40(8):1029-40.

19. Landsbergis PA, Cahill J. Labor union programs to reduce or prevent occupational stress in the United States. Int J Health Serv. 1994;24(1):105-29.

20. French SA, Story M, Fulkerson JA, Himes JH, Hannan P, Neumark-Sztainer D, et al. Increasing weight-bearing physical activity and calcium-rich foods to promote bone mass gains among 9-11 year old girls: outcomes of the Cal-Girls study. Int J Behav Nutr Phys Act. 2005;2:8.

21. Levers-Landis CE, Burant C, Drotar D, Morgan L, Trapl ES, Colabianchi $\mathrm{N}$, et al. A random controlled trial for the primary prevention of osteoporosis among preadolescent girl scouts: 1 year outcomes of a behavioral program. J Pediatr Psychol. 2005;30 (2): $155-65$

22. Baranowski T, Allen DD, Masse LC, Wilson M. Does participation in an intervention affect responses on self-reported questionnaires? Health Educ Res. 2006;21(suppl 1):i98-109.

23. Jago R, Baranowski T, Baranowski JC, Thompson D, Cullen KW, Watson K, et al. Fit for life Boy Scout badge: outcome evaluation of a troop and internet intervention. Prev Med. 2006;46:181-7.

24. Neumark-Sztainer D, Sherwood NE, Coller T, Hannan PJ. Primary prevention of disordered eating among pre-adolescent girls: feasibility and short-term effect of a community based intervention. J Am Diet Assoc. 2000;100(12):1466-73. 
25. Barbeau EM, Li Y, Calderon P, Hartman C, Quinn M, Markkanen $\mathrm{P}$, et al. Results of a union-based smoking cessation intervention for apprentice iron workers. Cancer Causes Control. 2006;17 (1):53-61.

26. Kwon VH, Ebaugh HR, Hagan J. The structure and functions of cell group ministry in a Korean Christian church. J Sci Study Relig. 1997;36:247-56.

27. Ellison CG. Religious involvement and subjective well-being. J Health Soc Behav. 1991;32:80-99.

28. Nooney J, Woodrum E. Religious coping and church-based social support as predictors of mental health outcomes: testing a conceptual model. J Sci Study Relig. 2002;41(2):359-68.

29. Levin J, Chatters LM, Taylor RJ. Religion health and medicine in African Americans: implications for physicians. J Natl Med Assoc. 2005;97(2):237-49.

30. Benjamins MR, Trinitapoli J, Ellison CG. Religious attendance, health maintenance beliefs, and mammography utilization: findings from a nationwide survey of Presbyterian women. J Sci Study Relig. 2006;45(4):597-607.

31. Cline KMC, Ferraro KF. Does religion increase the prevalence and incidence of obesity in adulthood? J Sci Study Relig. 2006;45 (2):269-81.

32. Wood W. Attitude change: persuasion and social influence. Annu Rev Psychol. 2000;51:539-70.

33. Fine GA, Harrington B. Tiny publics: small groups and civil society. Soc Theory. 2004;22(3):341-56.

34. Wenzel M. The social side of sanctions: personal and social norms as moderators of deterrence. Law Hum Behav. 2004;28 (5):547-67.

35. Terry DJ, Hoff MA. Group norms and the attitude-behavior relationship: a role for group identification. Pers Soc Psychol Bull. 1995;22(8):776-93.

36. Uchino BN, Cacioppo JT, Kiecolt-Glaser JK. The relationship between social support and physiological processes: a review with emphasis on underlying mechanisms and implications for health. Psychol Bull. 1996;119(3):488-531.

37. Putnam RD. Bowling alone: America's declining social capital. J Democracy. 1995;6:65-78.

38. Putnam RD. Bowling alone: the collapse and revival of American community. New York: Simon and Schuster; 2000.

39. Ziersch AM, Baum FE. Involvement in civil society groups: is it good for your health? J Epidemiol Community Health. 2004;58 (3):493-500.

40. Schuller T, Baron S, Field J. Social capital: a review and critique. In: Baron S, Field J, Schuller T, editors. Social capital: critical perspectives. Oxford: Oxford University Press; 2000. p. 1-38.

41. Passy F, Giugni M. Social networks and individual perceptions: explaining differential participation in social movements. Sociol Forum. 2001;16(1):123-53.

42. Costa FM, Jessor R, Turbin MS. College student involvement in cigarette smoking: the role of psychosocial and behavioral protection and risk. Nicotine Tob Res. 2007;9(2):213-24.

43. Hill TD, Burdette AM, Ellison CG, Musick MA. Religious attendance and the health behaviors of Texas adults. Prev Med. 2006;42:309-12.

44. Timberlake D, Rhee SH, Haberstick B, Hopfer C, Ehringer M, Lessem $\mathrm{J}$, et al. The moderating effects of religiosity on the genetic and environmental determinants of smoking initiation. Nicotine Tob Res. 2006;8(1):123-33.

45. Kim KK, Son H, Nam KA. Personal factors influencing Korean American men's smoking behavior: addiction, health, and age. Arch Psychiatr Nurs. 2005;19(1):35-41.

46. Hofstetter CR, Hovell MF, Lee J, Zakarian J, Park HR, Paik HY, et al. Tobacco use and acculturation among Californians of Korean descent: a behavioral epidemiological analysis. Nicotine Tob Res. 2004;6(3):481-9.
47. Lee SK, Sobal J, Frongillo EA Jr. Acculturation to U.S. society and health in Korean Americans. Soc Sci Med. 2000;51:159-73.

48. Hurh WM, Kim KC. Religious participation of Korean immigrants in the United States. J Sci Study Relig. 1990;29(1):19-34.

49. Hurh WM. The 1.5 generation: a cornerstone of the KoreanAmerican ethnic community. In: Kown HY, Kim S, editors. The emerging generation of Korean-Americans. Seoul Korea: Kyung Hee University Press; 1993.

50. Cha PT. Ethnic identity formation and participation in immigrant churches: second generation Korean American experiences. In: Kwon HY, Kim KC, Warner RS, editors. Korean Americans and their religions: pilgrims and missionaries from a different shore. University Park, PA: The Pennsylvania University Press; 2001. p. 141-56.

51. Goette RD. The transformation of a first generation church into a bilingual second-generation church. In: Kwon HY, Kim KC, Warner RS, editors. Korean Americans and their religions: pilgrims and missionaries from a different shore. University Park, PA: The Pennsylvania University Press; 2001. p. 125-40.

52. Ecklund EH. Models of civic responsibility: Korean Americans in congregations with different ethnic compositions. J Sci Study Relig. 2005;44(1):15-28.

53. Frey JH. Survey research by telephone. 2nd ed. Newbury Park, CA: Sage; 1989.

54. Song YJ, Hofstetter CR, Hovell MF, Paik HY, Park HR, Lee J, et al. Acculturation and health risk behavior among Californians of Korean descent. Prev Med. 2004;39:147-56.

55. U.S. Census Bureau, Population Census, 2000. Compiled by the Korean American coalition-census information center in partnership with the Center for Korean American and Korean Studies, California State University, Los Angeles. http://www.calstatela. edu/centers/ckaks/census_tables.html. Accessed 7 July 2008.

56. Korea National Statistical Office 1998 Annual Report on Statistics of Population [press release about birth, death, marriage, and divorce], August 23, 1999.

57. U.S. Department of Health and Human Services. National Center for Health Statistics. NHANES III reference manuals and reports (CD-ROM). Hyattsville, MD: Centers for Disease Control and Prevention; 1996.

58. Hughes SC, Hovell MF, Hofstetter CR, Irvin VL, Park HR, Paik HY. Home smoking policy and ETS exposure among Koreans in Seoul. Tob Control. 2008;17(1):71-2.

59. Suinn RM, Rickard-Figueroa K, Lew S, Vigil P. The Suinn-Lew Asian self-identity acculturation scale: an initial report. Educ Psychol Meas. 1987;47:401-7.

60. Suinn RM, Ahuna C, Khoo G. The Suinn-Lew Asian self-identity acculturation scale: concurrent and factorial validation. Educ Psychol Meas. 1992;52(4):1041-6.

61. Suinn RM, Khoo G, Ahuna C. The Suinn-Lew Asian self-identify acculturation scale: Cross-cultural information. J Multicult Couns Devel. 1995;23(3):139-50.

62. Michael J. Motivating operations. In: Cooper JO, Heron TE, Heward WL, editors. Applied behavior analysis. 2nd ed. Upper Saddle River, NJ: Prentice Hall/Merrill; 2007.

63. Kwon HY, Kim KC, Warner RS. Korean Americans and their religions: pilgrims and missionaries from a different Shore. University Park, PA: The Pennsylvania State University Press; 2001.

64. Hughes SC, Corcos IA, Hofstetter CR, Hovell MF, Irvin VL. Environmental tobacco smoke exposure among Korean American nonsmokers in California. Nicotine Tob Res. 2008;10(4):663-70.

65. Hofstetter CR, Jung KR, Raman R, Hovell MF, Irvin VL, Ni R. The first puff: forces in smoking initiation among Californians of Korean descent. Nicotine Tob Res. 2007;9(12):1277-86.

66. Ji M, Hofstetter CR, Hovell MF, Irvin VL, Song YJ, Lee J, et al. Smoking cessation patterns and predictors among adult Californians of Korean descent. Nicotine Tob Res. 2005;7(1):59-69. 
67. Long JS, Freese J. Regression models for categorical and limited dependent variables with stata. 2nd ed. College Station, TX: Stata Press; 2005.

68. Hughes SC. (PI) PSE rates and correlates: Koreans/Korean Americans. Grant awarded from the Flight Attendant Medical Research Institute, Young Clinical Scientist Award.

69. Kunitz SJ. Social capital and health. Br Med Bull. 2004;69: 61-73.

70. Valente TW, Watkins SC, Jato MN, Van der Straten A, Tsitsol LPM. Social network associations with contraceptive use among Cameroonian women in voluntary associations. Soc Sci Med. 1997;45(5):677-87.

71. Levy-Storms L. Strategies for diffusing public health innovations through older adults' health communication networks. Generations. 2005;29(2):70-5.

72. Steinman KJ, Bambakidis A. Faith-health collaboration in the United States: results from a nationally representative study. Am J Health Promot. 2008;22(4):256-63.

73. Campbell MK, Hudson MA, Resnicow K, Blakeney N, Paxton A, Baskin M. Church-based health promotion interventions: evidence and lessons learned. Annu Rev Public Health. 2007;28: 213-34.

74. Chong KH. What it means to be Christian: the role of religion in the construction of ethnic identity and boundary among secondgeneration Korean Americans. Sociol Relig; 59(3): 259-286.

75. Hovell MF, Wahlgren D, Russos S. Preventive medicine and cultural contingencies. In: Lamal PA, editor. Cultural contingencies: behavior analytic perspectives on cultural practices. Westport, CT: Praeger; 1997. p. 1-130.

76. Glass TA, McAtee MJ. Behavioral science at the crossroads in public health: extending horizons, envisioning the future. Soc Sci Med. 2006;62:1650-71.

77. Hovell MF, Wahlgren DR, Adams MA. The logical and impirical basis for the Behavioral Ecological Model: In: DiClemente RJ, Crosby RA, Kegler M, editors. Emerging theories and models in health promotion research and practice: strategies for enhancing public health. 2nd ed. San Francisco, CA: Jossey-Bass Publishers; 2009 (in press). 